\title{
PERILAKU PERJALANAN PENGGUNA SEPEDA MOTOR UNTUK TUJUAN BEKERJA DI PUSAT KOTA SEMARANG (STUDI KASUS: KORIDOR SEGITIGA EMAS)
}

\author{
Travel Behavior of Motorcycle User for Working Purposes in \\ Semarang City Center (Study Case: Segitiga Emas Corridor)
}

\section{Jonathan Badawi Wempi Suek ${ }^{1}$, dan Okto Risdianto Manullang ${ }^{1}$}

\begin{abstract}
Abstrak: Perilaku perjalanan dapat diukur melalui pola perjalanan yang terbentuk akibat penjadwalan aktivitas harian. Keputusan dalam menentukan pola perjalanan tidak terlepas dari aspek sosial-demografi, ekonomi dan lokasi tempat tinggal individu. Penelitian ini bertujuan untuk memahami hubungan antara pola perjalanan pekerja dengan aspek-aspek tersebut, serta menganalisis variabel prediktornya sebagai pendekatan dalam memahami penyediaan transportasi masal. Metode penelitian yang digunakan ialah pendekatan kuantitatif dengan menggunakan statistik deskriptif dan analisis multivariat melalui model persamaan struktural (SEM). Hasil penelitian menunjukan bahwa pekerja yang berstatus belum menikah dan pekerja yang belum memiliki anak/sudah tidak memiliki anak usia sekolah merupakan pekerja potensial yang dapat beralih moda ke Trans Semarang (49,5\%). Sebab, pekerja yang sudah menikah dengan memiliki dual-earner dalam rumah tangga, memiliki 1-2 anak usia sekolah dan rumah tangga berukuran kecil cenderung melakukan perjalanan kompleks dan sulit terfasilitasi oleh layanan Trans Semarang. Dengan demikian, layanan transportasi harus disesuaikan dengan karakteristik dan kebutuhan pekerja, minimal bagi potensial demand untuk menarik pengguna baru.
\end{abstract}

\section{Kata Kunci: perilaku perjalanan, aktivitas bekerja, sepeda motor}

\begin{abstract}
Travel behavior can be measured through travel patterns that are formed by scheduling daily activities. Decisions in determining travel patterns are inseparable from the socio-demographic, economic and residential aspects. This study aims to understand the relationship between the travel patterns of workers with these aspects, as well as analyzing predictor variables on understanding the provision of urban mass transportation. The research method used is quantitative approach by using descriptive statistics and multivariate analysis through structural equation model (SEM). The results showed that unmarried workers and workers who do not have children or already do not have children at school age are potential workers who can switch modes to Trans Semarang (49,5\%). Therefore, married workers with dual-earners in households, have 1-2 school-age children and small households tend to travel complex and difficult to facilitate by Trans Semarang service. Thus, transport services should be tailored to the characteristics and needs of workers, at least for potential demand to attract new users.
\end{abstract}

Keywords: travel behavior, work activity, motorscycle

\footnotetext{
${ }^{1}$ Departemen Perencanaan Wilayah dan Kota, Fakultas Teknik, Universitas Diponegoro
} 


\section{PENDAHULUAN}

Perkotaan diarahkan untuk berkembang secara berkelanjutan, yaitu pengembangan yang memaksimalkan potensi tanpa mengorbankan kebutuhan di masa yang akan datang. Pengembangan perkotaan yang berkelanjutan dipengaruhi beberapa aspek, meliputi populasi (sosial-ekologi), tata ruang, dan perilaku perjalanan (transportasi) (Alberti dalam Hasibuan et al, 2014). Kota sebagai tempat hidup, bekerja dan bermain memerlukan moda transportasi yang baik untuk mengurangi ketergantungan terhadap kendaraan pribadi. Masyarakat yang bergantung terhadap penggunaan kendaraan pribadi dalam melakukan pergerakannya akan mempengaruhi dan menimbulkan dampak buruk bagi lingkungan, keamanan dan kemacetan lalu lintas (Maat, 2009). Selain itu, pemilik kendaraan pribadi yang tinggal di pusat kota juga akan mengalami kesulitan dikarenakan keterbatasan lahan parkir, kemacetan lalu lintas, biaya asuransi dan parkir yang mahal (Giuliano \& Dargay dalam Maat, 2009). Dampak yang muncul seharusnya membuat perilaku perjalanan masyarakat di pusat kota tidak lagi bergantung kepada kendaraan pribadi.

Kepemilikan kendaraan pribadi dapat menjadi faktor penentu dalam perilaku perjalanan masyarakat (Maat, 2009). Kendaraan pribadi memberikan kemudahan dan keleluasaan dalam berpindah tempat, dimana hal tersebut sejalan dengan teori mobilitas. Namun, arahan pengembangan sistem transportasi sudah tidak lagi berorientasi untuk menyediakan kenyamanan pengguna kendaraan pribadi. Studi empiris mengungkapkan bahwa teori aksesibilitas lebih sesuai diterapkan dalam pengembangan sistem transportasi di pusat kota dibandingkan teori mobilitas. Hal tersebut dikarenakan konsep aksesibilitas dapat menjadi kerangka kerja yang jelas dalam integrasi sistem transportasi dan penggunaan lahan (Bertolini, le Clercq, \& Kapoen, 2005).

Konsep aksesibilitas menekankan integrasi antar moda transportasi dan pengembangan tata ruang yang mempermudah masyarakat dalam melakukan perjalanannya (Susantono, 2014). Perencanaan transportasi yang menunjang aksesibilitas akan memberi manfaat, yaitu menambah pilihan moda dan mengurangi penggunaan kendaraan pribadi (Handy, 2002). Hal tersebut mendukung sistem transportasi yang memfasilitasi manusia berpindah tempat tanpa perlu berkendara sendiri. Perilaku dasar masyarakat yang ingin menempuh perjalanan sesingkat-singkatnya (efektif) dan murah (efisien) membuat penyediaan transportasi umum harus mengakomodasi rutinitas masyarakat. Maka, perilaku perjalanan masyarakat dan tata ruang menjadi penting untuk dipertimbangkan, sebab kedua hal tersebut akan mempengaruhi pola perjalanan masyarakat.

Masyarakat melakukan perjalanan karena kegiatan dan pemenuhan kebutuhannya tidak dapat dipenuhi dalam satu tempat yang sama (Van Acker \& Witlox, 2007). Kegiatankegiatan tersebut antara lain untuk memenuhi kebutuhan jasmani, kebutuhan institusional, kewajiban individu dan preferensi pribadi (Vilhelmson, 1999). Perjalanan untuk bekerja (kegiatan institusional) ialah jenis pergerakan dengan tingkat motivasi terbesar, selain untuk tujuan pendidikan (Tamin, 2000). Pergerakan tersebut biasanya didominasi ke pusat aktivitas di pusat kota, sehingga ada penyediaan transportasi dan prasarana penunjang yang lebih baik. Hal tersebut sewajarnya akan mempengaruhi penggunaan transportasi umum, sebab tempat kerja yang memiliki akses yang baik terhadap transportasi umum cenderung menghindarkan penggunaan kendaraan pribadi (Shiftan \& Barlach, 2002; Chatman, 2003; Chen et al., 2008 dalam Maat, 2009). Meskipun dijelaskan seperti itu, tingkat penggunaan kendaraan pribadi untuk tujuan bekerja masih tinggi di beberapa kota besar di Indonesia. Oleh sebab itu, operasional transportasi umum di pusat kota harus didasari oleh kebutuhan pergerakan masyarakat (pola perjalanan).

Koridor Segitiga Emas Kota Semarang yang berada di pusat kota terdiri dari tiga jalan utama yaitu Jalan Pemuda, Jalan Pandanaran dan Jalan Gajah Mada. Berdasarkan 
RTRW Kota Semarang 2011-2031, kawasan ini memiliki rencana pola ruang dengan fungsi utama sebagai zona perkantoran, dan zona perdagangan dan jasa. Fungsi tersebut menjadikan kawasan ini memiliki tarikan pergerakan masyarakat yang besar. Transportasi umum, yaitu BRT Trans Semarang sudah melayani kawasan ini, dimana Jalan Pemuda telah dilayani lima koridor yaitu koridor I-V, Jalan Pandanaran dilayani dua koridor yaitu I \& V, dan Jalan Gajah Mada dilayani dua koridor meliputi koridor III \& V. Namun, lokasi yang berada di pusat kota dan terlayani oleh akses transportasi umum tidak membuat operasional Trans Semarang di koridor tersebut memiliki kinerja yang baik, khususnya pada aspek faktor muat. Faktor muat (load factor) yang dimiliki Trans Semarang pada koridor tersebut rata-rata sebesar 54\% (BLU Trans Semarang, 2017) atau dibawah standar minimal SK Dirjen Hubdat No 687 sebesar 70\%. Hal ini mengindikasikan operasional Trans Semarang belum sesuai dengan kebutuhan masyarakat, sehingga masyarakat masih menggunakan kendaraan pribadi sebagai pilihan utama dalam melakukan pergerakan untuk bekerja.

Ketidaksesuaian antara potensi tarikan yang besar dengan faktor muat Trans Semarang yang rendah menimbulkan dugaan bahwa masyarakat masih bergantung terhadap moda transportasi lain, khususnya sepeda motor. Ketergantungan tersebut diduga terjadi karena aktivitas pergerakan masyarakat tidak dapat terakomodasi oleh Trans Semarang. Penelitian ini akan membuktikan perilaku perjalanan pengguna sepeda motor yang bekerja di Koridor Segitiga Emas, sehingga dapat diketahui frekuensi perjalanan dan tautan perjalanan pekerja, dimana hal itu akan mempengaruhi keputusan pemilihan moda transportasi. Hasil dari penelitian ini diharapkan membantu dan menjadi bahan pertimbangan dalam memperbaiki sistem layanan transportasi umum dan penataan ruang di Kota Semarang.

Ketergantungan masyarakat kota dalam menggunakan sepeda motor masih tinggi di Indonesia. Kota Semarang tercatat memiliki 151.286 unit sepeda motor dengan populasi penduduk sebanyak 1.592.729 jiwa (BPS, 2016), dimana menunjukan kepemilikan sepeda motor sebanyak 95 unit tiap 1000 penduduk. Hal ini memang masih tergolong rendah ( $<150$ unit/1000 penduduk) jika berdasarkan tabel indikator tingkat ketergantungan Hung (2006). Namun, jika dibandingkan dengan moda angkutan lainnya, sepeda motor merupakan jenis kendaraan dengan prosentase jumlah terbanyak mencapai 79,58\% (BPS, 2016), sehingga mengasumsikan adanya ketergantungan terhadap penggunaan sepeda motor di Kota Semarang. Ketergantungan tersebut juga tercermin dari banyaknya volum sepeda motor yang berlalu lintas di pagi/sore hari, yaitu bertepatan dengan aktivitas pergi dan pulang bekerja.

Keragaman penggunaan lahan (mix-used) dan kualitas aksesibilitas di pusat kota seharusnya dapat mempermudah perjalanan masyarakat, khususnya bagi pekerja. Pusat kota diberbagai kota dunia, misalnya $57,5 \%$ pekerja di CBD Washington D.C, Amerika Serikat sudah melakukan perjalanan bekerja secara transit (Douglas, Evans, \& Quade, n.d.), sedangkan sebesar 53\% pekerja di Area Metropolitan Bangalore, India juga menggunakan bus dan kendaraan tidak bermotor untuk perjalanan bekerja (Manoj \& Verma, 2013), atau $58,1 \%$ pekerja di Kota Shangyu, sebuah kota berpenduduk 200.000 jiwa di bagian timur Tiongkok, juga menggunakan moda tidak bermotor untuk bekerja (Yang, Wang, Chen, Wan, \& Xu, 2007). Bagaimana dengan kota-kota besar di Indonesia? Penelitian terkait perilaku perjalanan di negara berkembang, khususnya di kota-kota di Indonesia belum banyak dilakukan. Padahal, analisis pola perjalanan dapat memperkaya pemahaman dalam pengambilan keputusan perjalanan dan menjadi data empiris dalam perencanaan guna lahan dan transportasi (Ma, Mitchell, \& Heppenstall, 2014), sehingga berguna dalam pengembangan kebijakan transportasi (Yang et al, 2007).

Kebijakan transportasi publik yang sesuai dengan pola perjalanan masyarakat sangat dibutuhkan untuk menunjang efektifitas dan efisiensinya. Hal tersebut dibutuhkan karena 
pusat kota cenderung memiliki tarikan pergerakan yang besar. Penyediaan transportasi yang baik akan membuat masyarakat tidak bergantung pada kendaraan pribadi. Saat ini, penyediaan angkutan umum di pusat Kota Semarang, seperti di Koridor Segitiga Emas belum mampu menjadi pilihan utama pekerja di wilayah tersebut. Meskipun berlokasi strategis dan adanya akses transportasi seharusnya bisa membuat pekerja di Koridor Segitiga Emas Kota Semarang memanfaatkan transportasi umum, khususnya Trans Semarang, sehingga menghindari penggunaan sepeda motor. Namun sebaliknya, peneliti menduga belum banyak pekerja yang menggunakan Trans Semarang untuk perjalanan bekerja.

\section{METODE PENELITIAN}

Penelitian ini didominasi oleh penggunaan data berupa angka-angka yang dikumpulkan melalui teknik observasi, kuesioner, dan literatur. Metode penelitian yang digunakan dalam penelitian mengacu kepada metode kuantitatif, sehingga teknik analisis yang digunakan berbasis statistik, seperti teknik deskriptif, dan teknik analisis multivariat melalui model persamaan struktural (SEM) dengan menggunakan software LISREL.

Penentuan jumlah sampel akan menggunakan pendekatan yang disesuaikan dengan alat analisis yang akan digunakan. Secara umum, penelitian ini mengacu pada analisis multivariat melalui SEM. Metode yang digunakan untuk mengestimasi parameter model adalah metode Maximum Likelihood (ML). Menurut Solimun (2002) ukuran sampel yang disarankan untuk penggunaan estimasi ML adalah sebesar 100-200 responden atau 5-10 kali dari jumlah variabel manifes pada seluruh variabel yang digunakan dalam model. Oleh karena penelitian ini menggunakan variabel manifes sebanyak 15 variabel, maka ukuran sampel yang harus dipenuhi antara $75-150$ responden.

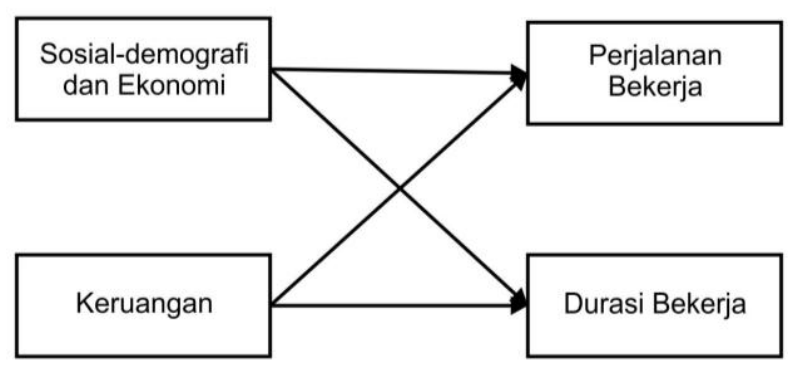

Sumber: Hasil Interpretasi Peneliti, 2017

\section{Gambar 1 Model Konseptual SEM}

111 sampel yang terkumpul diambil di tiga ruas yang membentuk Koridor Segitiga Emas secara proporsional untuk mendapatkan karakteristik pekerja pengguna sepeda motor yang representatif. Tempat kerja yang menjadi tempat penyeberan kuesioner berada di dekat Halte Trans Semarang untuk mengeliminasi kemungkinan pekerja bersifat captive terhadap penggunaan sepeda motor. Kuesioner dibagikan kepada pekerja dengan bantuan satu orang perantara di tiap tempat kerja. Peneliti memberikan pengarahan kepada perantara sebelum kuesioner dibagikan secara acak kepada rekan perantara.

Model konseptual (lihat Gambar 1) digunakan untuk menjelaskan hubungan antara kegiatan perjalanan dengan karakteristik sosial-demografi, ekonomi dan keruangan yang akan dibentuk pada analisis SEM. Karakteristik pekerja akan mempengaruhi perjalanan komuter yang dilakukannya. Kegiatan perjalanan diidentifikasi sebagai jumlah frekuensi, jarak tempuh, waktu tempuh dan biaya perjalanan. Oleh karena penelitian ini berfokus 
pada perjalanan pekerja, maka durasi aktivitas untuk bekerja juga dipertimbangkan untuk melengkapi hubungan yang ada.

\section{PEMBAHASAN}

Tautan perjalanan dijelaskan berdasarkan jenisnya yaitu perjalanan sederhana dan perjalanan kompleks (Ye, Pendyala, \& Gottardi, 2007). Perjalanan sederhana terbentuk apabila pekerja hanya melakukan 2 perjalanan yaitu perjalanan komuter. Perjalanan kompleks terbentuk apabila pekerja berpartisipasi terhadap kegiatan lain selama perjalanan komuter sehingga membentuk frekuensi perjalanan 3 kali atau lebih. Pengguna sepeda motor untuk tujuan bekerja di Koridor Segitiga Emas lebih banyak yang melakukan perjalanan dengan frekuensi 2 perjalanan per hari atau perjalanan simpel, sedangkan pekerja yang melakukan perjalanan kompleks sebanyak 30\%.

Tautan perjalanan yang dilakukan oleh pekerja dapat dijelaskan berdasarkan jenisnya yaitu simpel dan kompleks. Tautan perjalanan simpel akan selalu memiliki bentuk tautan bernotasi H-W-H yaitu perjalanan dari rumah - tempat kerja - rumah. Sedangkan, tautan perjalanan kompleks akan bervariasi bergantung kepada kegiatan yang dilakukan oleh pekerja selama melakukan perjalanan komuter. Notasi “-X-“ merupakan perjalanan pekerja saat berpartisipasi pada kegiatan non-bekerja di suatu tempat. Bentuk tautan H-XW-H merupakan tautan perjalanan kompleks yang paling banyak terjadi, dimana kegiatan non-bekerja dilakukan saat perjalanan pergi bekerja. Sedangkan, bentuk tautan H-W-X-H dilakukan oleh pekerja sebanyak 5\%, dimana pekerja melakukan kegiatan non-bekerja saat perjalanan pulang bekerja. Bentuk tautan $\mathrm{H}-\mathrm{W}-\mathrm{X}-\mathrm{W}-\mathrm{H}$ merupakan bentuk tautan perjalanan saat pekerja melakukan mid-day trip.

Tabel 1. Jenis Tautan Perjalanan Komuter Pekerja

\begin{tabular}{|l|r|}
\hline \multicolumn{1}{|c|}{ Jenis Tautan Perjalanan } & \multicolumn{1}{c|}{ Persentase } \\
\hline H-W-H & $70,27 \%$ \\
\hline H-X-W-H & $10,81 \%$ \\
\hline H-W-X-H & $5,41 \%$ \\
\hline H-W-X-W-H & $4,50 \%$ \\
\hline H-X-W-X-H & $3,60 \%$ \\
\hline H-W-H-W-H & $0,9 \%$ \\
\hline H-W-X-X-H & $0,9 \%$ \\
\hline H-W-X-X-W-H & $0,9 \%$ \\
\hline H-X-X-W-X-X-H & $0,9 \%$ \\
\hline H-X-W-W-W-H-W-H & $0,9 \%$ \\
\hline H-X-W-X-W-X-X-X-H & $0,9 \%$ \\
\hline
\end{tabular}

Bentuk tautan perjalanan kompleks yang dilakukan pekerja saat perjalanan komuter memiliki variasi yang cukup banyak. Bentuk tautan perjalanan dengan 3 trip sebanyak 2 bentuk, 4 trip sebanyak 4 bentuk, dan 5 sampai 8 trip masing-masing sebanyak 1 bentuk. Variasi tersebut bergantung kepada tanggungjawab dan selera pekerja untuk memanfaatkan atau memaksimalkan perjalanan komuternya.

Hubungan sosial-ekonomi dan keruangan terhadap pola perjalanan pekerja dinyatakan dengan analisis SEM. Gambar 2 berikut ini merupakan model fit dari karakteristik pekerja yang menggunakan sepeda motor untuk tujuan bekerja di Koridor Segitiga Emas. Hubungan panah antar variabel eksogen dan endogen menjelaskan 
Tangga $\left(\mathrm{y}_{7}\right)$, Pendapatan Pribadi $\left(\mathrm{y}_{8}\right)$, dan Lokasi Tempat Tinggal $\left(\mathrm{y}_{10}\right)$. Berdasarkan model fit, berikut ini merupakan persamaan pengukuran dan persamaan struktural yang terbentuk.

- Persamaan Pengukuran

$$
\begin{aligned}
& \mathrm{x}_{1}=0,339 \mathrm{y}_{1}-0,734 \mathrm{y}_{5}+0,662 \mathrm{y}_{6}+0,940 \mathrm{y}_{7} \\
& \mathrm{x}_{2}=-0,934 \mathrm{y}_{10} \\
& \mathrm{x}_{3}=0,399 \mathrm{y}_{2}-0,196 \mathrm{y}_{4} \\
& \mathrm{x}_{4}=-0,488 \mathrm{y}_{5}+0,438 \mathrm{y}_{6}+0,344 \mathrm{y}_{7} \\
& \mathrm{x}_{5}=0,171 \mathrm{y}_{4}-0,237 \mathrm{y}_{8} \\
& \text { Persamaan Struktrual } \\
& \mathrm{x}_{1}=0,233 \mathrm{x}_{5}+\varepsilon_{5} \\
& \mathrm{x}_{2}=0,148 \mathrm{x}_{1}+\varepsilon_{1} \\
& \mathrm{x}_{3}=0,752 \mathrm{x}_{2}+\varepsilon_{2} \\
& \mathrm{x}_{4}=0,609 \mathrm{x}_{2}+\varepsilon_{2}
\end{aligned}
$$

\section{Persamaan Pengukuran dan Struktural Trip Frekuensi}

Persamaan pengukuran Trip Frekuensi dinotasikan dengan persamaan $\mathrm{x}_{1}=\gamma_{11} \mathrm{y}_{1}+$ $\gamma_{15} \mathrm{y}_{5}+\gamma_{16} \mathrm{y}_{6}+\gamma_{17} \mathrm{y}_{7}$ dan persamaan struktural dinyatakan dengan notasi $\mathrm{x}_{1}=\beta_{15} \mathrm{x}_{5}+\varepsilon_{5}$ yang memiliki nilai beta $(\beta)$. Berikut ini merupakan nilai estimasi standardized pada gamma $(\gamma)$ dan beta $(\beta)$ dari persamaan pengukuran dan struktural Trip Frekuensi.

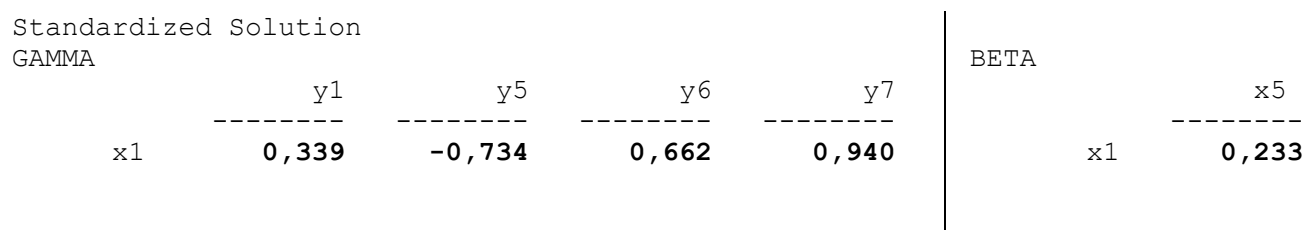

Variabel yang mempengaruhi Trip Frekuensi $\left(\mathrm{x}_{1}\right)$ didominasi oleh variabel berunsur/berasal dari struktur keluarga. Latar belakang keluarga pekerja akan mempengaruhi Trip Frekuensi karena peluang partisipasi pekerja terhadap kegiatan nonbekerja selama perjalanan komuter akan bertambah dengan adanya tanggungjawab terhadap anggota keluarga lainnya. Latar belakang ini tidak terlepas dari status pernikahan pekerja, sebab struktur rumah tangga akan berbeda pada pekerja yang telah menikah dan belum menikah. 


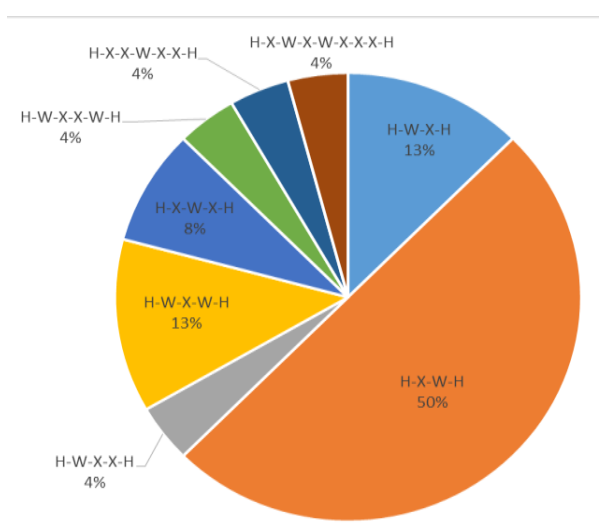

Sumber: Hasil Analisis Peneliti, 2017

\section{Gambar 3 Persentase Tautan Perjalanan Kompleks Pekerja yang Sudah Menikah}

Pekerja yang mendominasi dalam populasi ialah pekerja yang sudah menikah. Tautan perjalanan kompleks yang sering dilakukan pekerja tersebut ialah tautan dengan 3 perjalanan (63\%). Bentuk perjalanan tersebut dinotasikan dengan $\mathrm{H}-\mathrm{X}-\mathrm{W}-\mathrm{H}$ dan $\mathrm{H}-\mathrm{W}-\mathrm{X}-\mathrm{H}$. Notasi '-X-' merupakan perjalanan untuk melakukan kegiatan non-bekerja. Kegiatan mengantar anak ke sekolah merupakan kegiatan yang paling sering dilakukan oleh pekerja pada tautan perjalanan berbentuk H-X-W-H. Hal tersebut dilakukan karena pekerja yang sudah menikah memiliki tanggungjawab terhadap anggota keluarga lainnya, khususnya kepada anak. Hal ini sejalan dengan kuatnya $(0,940)$ pengaruh variabel jumlah anggota usia anak dalam rumah tangga $\left(\mathrm{y}_{7}\right)$ terhadap Trip Frekuensi $\left(\mathrm{x}_{1}\right)$. Perjalanan dengan bentuk $\mathrm{H}-$ $\mathrm{W}-\mathrm{X}-\mathrm{H}$ banyak dilakukan ketika pekerja akan melakukan kegiatan berbelanja atau makan malam setelah pulang dari kantor. Selain itu, kegiatan menjemput keluarga juga muncul dalam diari perjalanan pekerja yang melakukan perjalanan komuter. Perjalanan dengan notasi $\mathrm{H}-\mathrm{W}-\mathrm{X}-\mathrm{W}-\mathrm{H}$ merupakan perjalanan komuter dengan mid-day trip. Perjalanan di siang hari tersebut ialah kegiatan perawatan berupa makan siang yang membutuhkan penggunaan sepeda motor untuk menjangkau tempat makan.

\section{Tabel 2. Jumlah Pekerja dan Tautan Perjalanan Pekerja}

\begin{tabular}{|c|l|r|r|}
\hline $\begin{array}{c}\text { Jumlah Pekerja dalam } \\
\text { RT }\end{array}$ & \multicolumn{1}{|c|}{$\begin{array}{c}\text { Tautan } \\
\text { Perjalanan }\end{array}$} & $\begin{array}{c}\text { Persentase } \\
\text { Pekerja }\end{array}$ & $\begin{array}{c}\text { Perbandingan antar } \\
\text { Tautan Perjalanan }\end{array}$ \\
\hline \multirow{2}{*}{1} & Simple & $17 \%$ & $73 \%$ \\
\cline { 2 - 4 } & Kompleks & $6 \%$ & $27 \%$ \\
\hline \multirow{2}{*}{2} & Simple & $35 \%$ & $67 \%$ \\
\cline { 2 - 4 } & Kompleks & $17 \%$ & $33 \%$ \\
\hline \multirow{3}{*}{$>3$} & Simple & $18 \%$ & $74 \%$ \\
\cline { 2 - 4 } & Kompleks & $6 \%$ & $26 \%$ \\
\hline
\end{tabular}

Sumber: Hasil Survei Peneliti, 2017

Adanya pekerja lain dalam rumah tangga akan mempengaruhi jumlah frekuensi perjalanan pekerja saat melakukan perjalanan komuter. Jumlah pekerja lebih dari 1 akan menambah peluang jumlah frekuensi yang dilakukan pekerja. Namun, kurva pada Gambar 4.14 cenderung menurun dengan semakin banyaknya jumlah pekerja dalam satu rumah tangga. Hal tersebut sejalan dengan pengaruh negatif variabel ukuran rumah tangga $\left(\mathrm{y}_{5}\right)$ 
terhadap Trip Frekuensi $\left(\mathrm{x}_{1}\right)$. Trip Frekuensi bertambah ketika pekerja melakukan sharing moda dan hal ini lebih berpeluang terjadi ketika hanya ada 2 pekerja dalam rumah tangga. Perjalanan kompleks lebih banyak muncul pada perjalanan komuter apabila rumah tangga memiliki dual-earner. Rumah tangga dengan dual-earner lebih banyak muncul pada ukuran rumah tangga 3-4 jiwa dengan komposisi 2 anggota usia dewasa. Hal ini menjelaskan bahwa status pekerja dalam rumah tangga tersebut ialah suami dan istri.

Tabel 3. Jenis Tautan Perjalanan dan Status Nikah pada Rumah Tangga dengan 2 Pekerja

\begin{tabular}{|c|r|r|r|}
\hline Tautan Perjalanan & Nikah & \multicolumn{2}{|c|}{ Belum Menikah } \\
\hline Simpel & 21 & 18 & Jumlah \\
\hline Kompleks & 18 & 1 & 19 \\
\hline Jumlah & 39 & 19 & \\
\hline
\end{tabular}

Pekerja yang sudah menikah akan memiliki tanggungjawab lebih terhadap anggota keluarga lainnya. Pada dasarnya, frekuensi perjalanan minimal yang dilakukan pekerja setiap hari ialah 2 perjalanan yaitu perjalanan pergi-pulang bekerja. Namun, pekerja yang telah menikah berpeluang untuk melakukan perjalanan tambahan ketika dalam kegiatan komuter. Perjalanan tambahan tersebut dilakukan untuk memenuhi kebutuhan yang lain terutama untuk berpartisipasi pada kegiatan perawatan (maintenance activity). Kegiatan perawatan yang terrekam melalui diari perjalanan pekerja berupa kegiatan mengantar anak, mengantar/menjemput keluarga yang juga bekerja, kegiatan belanja, makan siang dan makan malam. Pekerja yang sudah menikah namun pencari nafkah tunggal cenderung melakukan tautan dengan 2 perjalanan per hari atau perjalanan simpel. Hal ini disebabkan karena kegiatan perawatan yang berkaitan dengan rumah tangga dapat ditangani oleh pasangannya. Berbeda dengan pekerja yang sudah menikah dan memiliki 2 pencari nafkah dalam rumah tangganya yang cenderung melakukan perjalanan kompleks.

Tabel 4. Status Pernikahan dan Jumlah Pekerja dalam RT terhadap Trip Frekuensi

\begin{tabular}{|c|c|c|c|c|}
\hline $\begin{array}{c}\text { Status } \\
\text { Pernikahan }\end{array}$ & & & Perband & $\tan$ \\
\hline \multirow{6}{*}{$\begin{array}{c}\text { Pekerja yang } \\
\text { belum menikah }\end{array}$} & \multirow{2}{*}{1} & \multirow{2}{*}{$16 \%$} & Simpel & $86 \%$ \\
\hline & & & Kompleks & $14 \%$ \\
\hline & \multirow{2}{*}{2} & \multirow{2}{*}{$42 \%$} & Simpel & $95 \%$ \\
\hline & & & Kompleks & $5 \%$ \\
\hline & \multirow{2}{*}{$\geq 3$} & \multirow{2}{*}{$42 \%$} & Simpel & $74 \%$ \\
\hline & & & Kompleks & $26 \%$ \\
\hline \multirow{6}{*}{$\begin{array}{c}\text { Pekerja yang } \\
\text { sudah menikah }\end{array}$} & \multirow{2}{*}{1} & \multirow{2}{*}{$29 \%$} & Simpel & $68 \%$ \\
\hline & & & Kompleks & $32 \%$ \\
\hline & \multirow{2}{*}{2} & \multirow{2}{*}{$59 \%$} & Simpel & $54 \%$ \\
\hline & & & Kompleks & $46 \%$ \\
\hline & \multirow{2}{*}{$\geq 3$} & \multirow{2}{*}{$12 \%$} & Simpel & $75 \%$ \\
\hline & & & Kompleks & $25 \%$ \\
\hline
\end{tabular}

Sumber: Hasil Survei Peneliti, 2017

Hal menarik terlihat dari perbandingan pekerja yang belum menikah dalam melakukan perjalanan simpel atau kompleks. Pekerja yang belum menikah lebih banyak 
melakukan perjalanan simpel, meskipun memiliki jumlah pekerja dalam rumah tangga yang berbeda-beda. Hal tersebut dapat dijelaskan karena pekerja yang belum menikah tidak memiliki tanggungjawab yang mengikat terhadap anggota keluarga lainnya.

Hubungan yang terjadi antar variabel jenis kelamin $\left(\mathrm{y}_{1}\right)$ dan durasi bekerja $\left(\mathrm{x}_{5}\right)$ terhadap variabel Trip Frekuensi $\left(\mathrm{x}_{1}\right)$ memiliki nilai estimasi yang lemah yaitu sebesar 0,339 dan 0,233. Kedua variabel mempengaruhi secara positif atau berbanding lurus dengan frekuensi perjalanan yang akan dilakukan bekerja. Pekerja berjenis kelamin perempuan cenderung melakukan perjalanan kompleks yaitu berpartisipasi pada kegiatan non-bekerja pada perjalanan komuter. Selain itu, pekerja yang memiliki durasi bekerja yang lebih lama (> 8 jam) atau saat melakukan lembur akan membuat pekerja tersebut memiliki waktu pulang di malam hari, sehingga cenderung meningkatkan trip frekuensi pada perjalanan pulang bekerja. Pada beberapa kasus perjalanan yang tercatat dalam diari perjalanan, waktu pulang pekerja pada malam hari berhimpitan dengan jam makan malam. Hal ini membuat pekerja akan melakukan efisiensi dengan melakukan kegiatan perawatan berupa makan malam, atau membeli makan malam sebelum sampai di rumah. Perjalanan ini dinotasikan dengan tautan berbentuk $\mathrm{H}-\mathrm{W}-\mathrm{X}-\mathrm{H}$.

Hubungan variabel-variabel yang mempengaruhi Trip Frekuensi mengartikan bahwa pekerja yang memiliki anak, rumah tangga dengan dual-earner, namun memiliki ukuran rumah tangga yang kecil cenderung membuat pekerja tersebut melakukan perjalanan kompleks daripada perjalanan simpel. Perjalanan kompleks lebih berpeluang terjadi apabila pekerja tersebut berjenis kelamin perempuan, dan memiliki durasi bekerja yang relatif lebih lama. Durasi bekerja berperan sebagai variabel perantara yang telah dipengaruhi oleh variabel Status Pernikahan ( $\left.\mathrm{y}_{4}\right)$ dan Pendapatan Pribadi Pekerja ( $\left.\mathrm{y}_{8}\right)$.

\section{Persamaan Pengukuran dan Struktural Jarak Tempuh Perjalanan}

Persamaan pengukuran Jarak Tempuh Perjalanan dinotasikan dengan $\mathrm{x}_{2}=\gamma_{20} \mathrm{y}_{10}$. Selain dipengaruhi secara langsung oleh variabel eksogen dalam persamaan pengukuran, Jarak Tempuh Perjalanan juga dipengaruhi oleh variabel endogen Trip Frekuensi melalui persamaan struktural. Berikut ini merupakan nilai estimasi yang sudah terstandarisasi pada gamma dan beta.

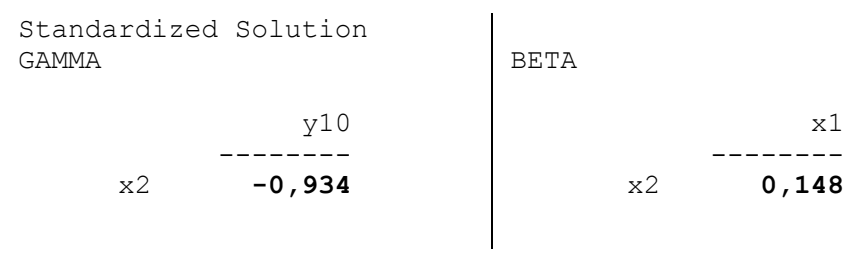

Variabel Lokasi Tempat Tinggal ( $\left.\mathrm{y}_{10}\right)$ mempengaruhi Jarak Tempuh Perjalanan $\left(\mathrm{x}_{2}\right)$ dengan nilai estimasi -0,934 secara negatif. Lokasi tempat tinggal diklasifikasi berdasarkan jaraknya ke pusat kota, meliputi Pusat kota (3), Sub-pusat kota (2), dan Pinggiran kota (1). Meskipun bernilai negatif, variabel $\mathrm{y}_{10}$ tidak berarti mempengaruhi Jarak Tempuh Perjalanan secara berbanding terbalik. Namun tetap mempengaruhi secara berbanding lurus, karena pengklasifikasian Lokasi Tempat Tinggal dilakukan secara terbalik yaitu Pusat Kota memiliki nilai yang tertinggi. Dengan demikian, hubungan tersebut tetap menjelaskan bahwa semakin lokasi tempat tinggal mendekat ke pusat kota, maka akan mengurangi Jarak Tempuh Perjalanan pekerja, begitupun sebaliknya. 


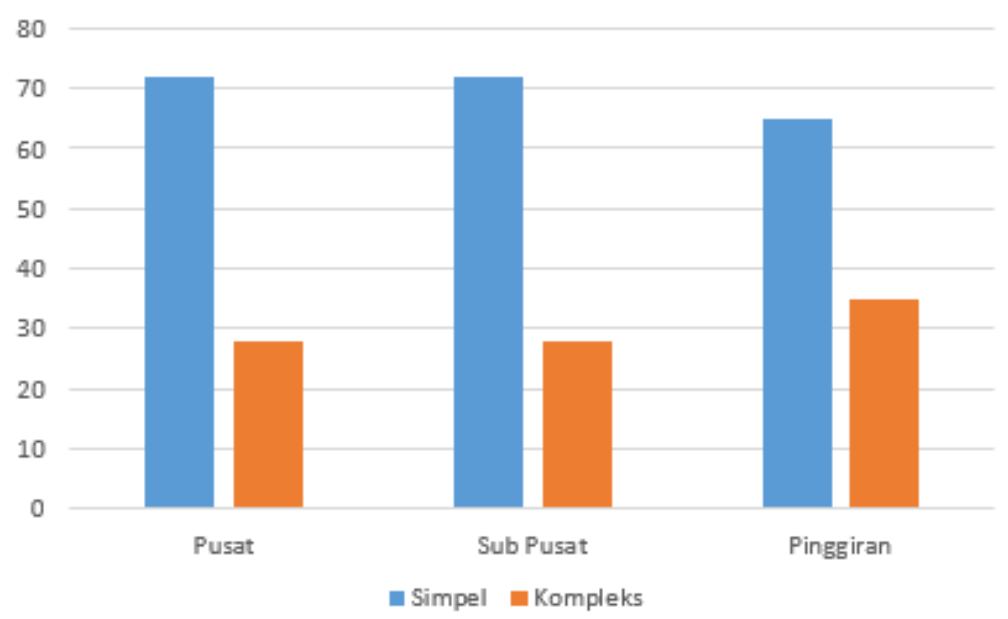

Sumber: Hasil Analisis Peneliti, 2017

Gambar 4 Lokasi Tempat Tinggal Pekerja dan Tautan Perjalanan Bekerja

Tautan perjalanan yang banyak dilakukan pekerja berdasarkan lokasi tempat tinggal ialah tautan perjalanan simpel. Namun, perjalanan kompleks lebih banyak muncul apabila pekerja memiliki lokasi tempat tinggal di pinggiran kota. Perbandingan tautan perjalanan simpel dan kompleks pekerja pengguna sepeda motor yang memiliki tempat tinggal di pusat kota dan sub pusat kota memiliki perbandingan 3:1, sedangkan pinggiran kota sebesar 2:1. Dengan demikian, Lokasi Tempat Tinggal memang mempengaruhi Jarak Tempuh Perjalanan Bekerja, namun tidak secara signifikan mempengaruhi tautan perjalanan yang dilakukan pekerja, khususnya yang tinggal di Pusat Kota dan Sub-Pusat Kota.

Trip Frekuensi $\left(\mathrm{x}_{1}\right)$ mempengaruhi Jarak Tempuh Perjalanan yang dilakukan pekerja melalui persamaan struktural yang terbentuk. Hubungan kausal antar variabel endogen ini memang wajar terjadi, sebab semakin banyak frekuensi perjalanan yang dilakukan, maka akan menambah jarak yang perlu ditempuh oleh pekerja. Pekerja dengan perjalanan simpel yaitu dengan jumlah frekuensi sebanyak 2 perjalanan akan memiliki Jarak Tempuh minimalnya. Jika pekerja tersebut melakukan perjalanan kompleks yaitu dengan lebih dari 2 perjalanan, maka akan menambah jarak tempuh yang dibutuhkan. Pada beberapa kasus perjalanan komuter yang memiliki jumlah frekuensi 3 perjalanan, penambahan frekuensi perjalanan tidak akan menambah jarak yang ditempuh, apabila lokasi pemberhentian berada di jalur yang sama dengan jalur berangkat-pulang kantor. Kasus-kasus seperti itu memiliki bentuk tautan perjalanan dengan notasi $\mathrm{H}-\mathrm{X}-\mathrm{W}-\mathrm{H}$ atau $\mathrm{H}-\mathrm{W}-\mathrm{X}-\mathrm{H}$.

Trip Frekuensi $\left(\mathrm{x}_{1}\right)$ mempengaruhi Jarak Tempuh Perjalanan $\left(\mathrm{x}_{2}\right)$ tidak terlepas dari variabel indikator Trip Frekuensi itu sendiri. Pada hubungan ini, Trip Frekuensi berperan sebagai variabel perantara yang mempengaruhi variabel endogen lain. Variabel Jenis Kelamin ( $\left.\mathrm{y}_{1}\right)$, Ukuran Rumah Tangga $\left(\mathrm{y}_{5}\right)$, Jumlah Pekerja $\left(\mathrm{y}_{6}\right)$, dan Jumlah Anggota Usia Anak $\left(\mathrm{y}_{7}\right)$ mempengaruhi Jarak Tempuh Perjalanan secara tidak langsung. Jumlah anak dalam rumah tangga menjadi variabel yang paling kuat mempengaruhi Trip Frekuensi, sehingga variabel inipun juga memiliki pengaruh yang lebih besar dari 3 variabel indikator lainnya. Variabel Jumlah Anggota Usia Anak dalam Rumah Tangga $\left(\mathrm{y}_{7}\right)$ memiliki nilai estimasi yang positif-positif untuk mempengaruhi Jarak Tempuh Perjalanan $\left(\mathrm{x}_{2}\right)$. Hal ini menjelaskan bahwa adanya anak dalam keluarga akan mempengaruhi frekuensi perjalanan serta menambah jarak tempuh yang perlu dilakukan secara berbanding lurus. Keberadaan 
anak yang mempengaruhi jarak tempuh perjalanan pekerja apabila pekerja tersebut melakukan kegiatan non-bekerja saat melakukan perjalanan komuter. Tempat partisipasinya pun tidak berada tepat di jalur pulang-pergi pekerja meskipun searah, sehingga ada kompensasi jarak tambahan saat melakukan kegiatan non-bekerja tersebut. Kegiatan non-bekerja yang terekam pada diari perjalanan pekerja ialah ketika pekerja melakukan perjalanan perawatan berupa mengantar anak ke sekolah dan antar/jemput anak.

Tabel 5. Jumlah Anak dalam Keluarga Pekerja terhadap Tautan Perjalanan

\begin{tabular}{|c|r|l|r|}
\hline \multicolumn{2}{|c|}{$\begin{array}{c}\text { Jumlah Anak dalam } \\
\text { Keluarga Pekerja }\end{array}$} & \multicolumn{2}{c|}{$\begin{array}{c}\text { Tautan Perjalanan yang } \\
\text { Terbentuk }\end{array}$} \\
\hline \multirow{2}{*}{0} & \multirow{2}{*}{$32 \%$} & Simpel & $84 \%$ \\
\cline { 3 - 4 } & & Kompleks & $16 \%$ \\
\hline \multirow{2}{*}{1} & \multirow{2}{*}{$33 \%$} & Simpel & $60 \%$ \\
\cline { 3 - 4 } & & Kompleks & $40 \%$ \\
\hline \multirow{2}{*}{2} & \multirow{2}{*}{$29 \%$} & Simpel & $62 \%$ \\
\cline { 3 - 4 } & & Kompleks & $38 \%$ \\
\hline \multirow{2}{*}{$>3$} & \multirow{2}{*}{$6 \%$} & Simpel & $66 \%$ \\
\cline { 3 - 4 } & & Kompleks & $33 \%$ \\
\hline
\end{tabular}

Sumber: Hasil Survei Peneliti, 2017

Pekerja yang memiliki jumlah anak 1-2 dalam rumah tangganya cenderung melakukan perjalanan kompleks lebih banyak dari pekerja yang memiliki jumlah anak 0 atau >3. Hal ini dapat terjadi karena keberadaan anak dalam keluarga meningkatkan tanggungjawab anggota usia dewasa dalam berpartisipasi atau ikut menentukan perjalanan anak tersebut. Hal ini terjadi pada pekerja yang memiliki anak usia balita atau sekolah, sehingga pekerja perlu melakukan kegiatan mengantar anak ke sekolah atau menitipkan anak. Selain itu, meskipun perbandingan perjalanan kompleks pada keluarga dengan jumlah $>3$ anak sebesar 33\%, namun karena memiliki populasi yang sedikit $6 \%$, pengaruh tersebut sedikit bias.

\section{Persamaan Pengukuran dan Struktural Waktu Tempuh Perjalanan}

Pekerja pengguna sepeda motor yang bekerja di pusat kota memiliki waktu tempuh perjalanan yang dipengaruhi oleh 3 variabel, meliputi 2 variabel eksogen dan 1 variabel endogen. Variabel Usia $\left(\mathrm{y}_{2}\right)$, dan Status Pernikahan Pekerja $\left(\mathrm{y}_{4}\right)$ mempengaruhi secara langsung Waktu Tempuh Perjalanan dengan notasi persamaan $\mathrm{x}_{3}=\gamma_{32} \mathrm{y}_{2}+\gamma_{34} \mathrm{y}_{4}$. Selain dipengaruhi secara langsung oleh variabel eksogen dalam persamaan pengukuran, Waktu Tempuh Perjalanan juga dipengaruhi oleh variabel endogen Jarak Tempuh Perjalanan $\left(\mathrm{x}_{2}\right)$. Berikut ini merupakan nilai estimasi yang terstandarisasi pada gamma $(\gamma)$ dan beta $(\beta)$.

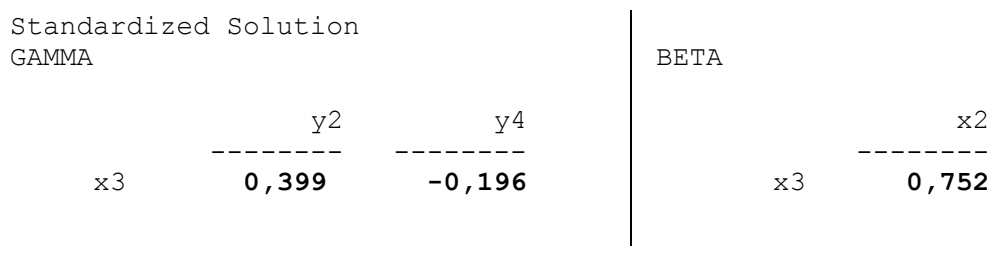

Variabel Jarak Tempuh Perjalanan $\left(\mathrm{x}_{2}\right)$ dan Usia Pekerja $\left(\mathrm{y}_{2}\right)$ memiliki nilai estimasi yang positif terhadap Waktu Tempuh Perjalanan komuter pekerja. Variabel Jarak Tempuh tergolong mempengaruhi secara kuat dengan nilai estimasi 0,752. Variabel Usia Pekerja 
meskipun lemah, namun memiliki nilai estimasi yang lebih kuat daripada variabel Status Pernikahan $\left(\mathrm{y}_{4}\right)$ dengan nilai sebesar 0,399. Berdasarkan Gambar 4.15, perbedaan titik lembah atau bukit yang jauh antar Jarak Tempuh dan Waktu Tempuh pada satu pekerja menunjukan pekerja tersebut melakukan perjalanan kompleks. Perjalanan kompleks banyak dijumpai pada rentang usia 20an-30an. Semakin berumur seseorang, maka ia berpeluang memiliki status sebagai individu yang telah menikah. Namun, status pernikahan memiliki pengaruh yang negatif atau berbanding terbalik terhadap waktu tempuh yang dilakukan pekerja dengan nilai estimasi -0,196.

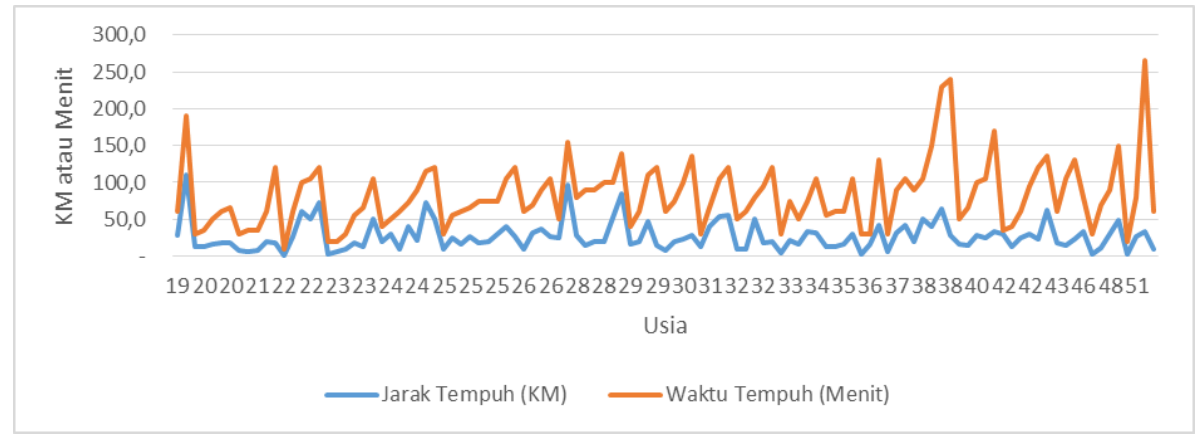

Sumber: Hasil Analisis Peneliti, 2017

\section{Gambar 5 Jarak Tempuh dan Waktu Tempuh berdasarkan Usia Pekerja}

Persamaan struktural yang terjadi antara variabel Jarak Tempuh Perjalanan $\left(\mathrm{x}_{2}\right)$ terhadap Waktu Tempuh Perjalanan $\left(\mathrm{x}_{3}\right)$ menjelaskan bahwa waktu tempuh perjalanan yang dilakukan pekerja juga dipengaruhi secara tidak langsung oleh variabel-variabel indikator Jarak Tempuh Perjalanan. Variabel tersebut antara lain Lokasi Tempat Tinggal $\left(\mathrm{y}_{10}\right)$ dan Trip Frekuensi $\left(\mathrm{x}_{1}\right)$ dengan pengaruh yang lebih kuat berasal dari pengaruh lokasi tempat tinggal pekerja. Pengaruh variabel $\mathrm{y}_{10}$ terhadap Waktu Tempuh Perjalanan memiliki nilai negatif-positif, namun makna "negatif" pada variabel $\mathrm{y}_{10}$ tetap bermakna positif, sehingga hubungan tidak langsung antara variabel $\mathrm{y}_{10}$ terhadap $\mathrm{x}_{3}$ tetap positif-positif.

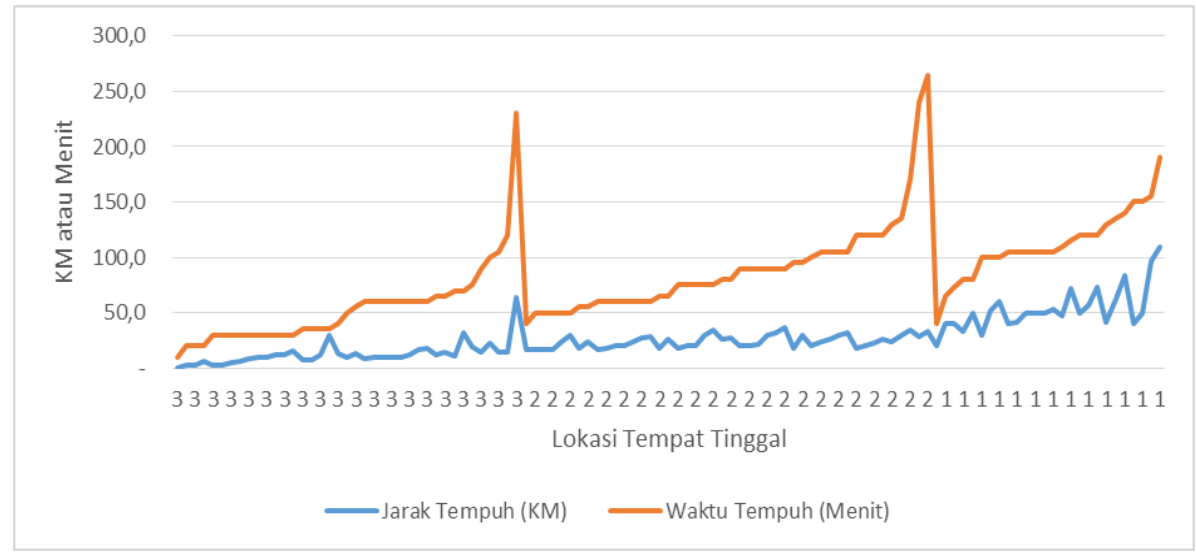

Sumber: Hasil Analisis Peneliti, 2017

Gambar 6 Jarak Tempuh Dan Waktu Tempuh Berdasarkan Lokasi Tempat Tinggal 
Lokasi tempat tinggal pekerja yang berada di pusat kota, sub-pusat kota dan pinggiran kota memiliki fungsi jarak yang berbeda-beda. Perkerja yang tinggal di pinggiran kota akan memiliki Waktu Tempuh yang lebih panjang karena jarak yang lebih jauh. Namun, fungsi jarak tidak berdiri sendiri, sebab masih ada fungsi hambatan lalu lintas yang dapat ditemui pekerja saat perjalanan komuter. Dengan rute yang lebih panjang, pekerja berpeluang untuk mengalami kemacetan lalu lintas yang lebih banyak di beberapa titik. Berdasarkan diari perjalanan, perjalanan pulang kerja cenderung memiliki Waktu Tempuh perjalanan yang lebih lama meskipun dalam perjalanan simpel.

Jarak Tempuh Perjalanan $\left(\mathrm{x}_{2}\right)$ yang dikonstruk oleh Trip Frekuensi $\left(\mathrm{x}_{1}\right)$ memperlihatkan bahwa jumlah perjalanan yang melebihi 2 perjalanan menunjukan pekerja melakukan kegiatan lain saat perjalanan komuter. Partisipasi pekerja terhadap kegiatan non-bekerja selama perjalanan komuter pasti akan mempengaruhi Waktu Tempuh Perjalanan. Jadi, selain hambatan lalu lintas yang akan ditemui selama melakukan perjalanan, partisipasi pekerja terhadap kegiatan non-bekerja selama perjalanan komuter juga akan menambah waktu perjalanan. Waktu tempuh perjalanan tetap bertambah meskipun tempat pemberhentian dalam melakukan kegiatan non-bekerja berada di jalur yang sama dengan jalur komuter pekerja.

\section{Persamaan Pengukuran dan Struktural Biaya Perjalanan}

Persamaan pengukuran Biaya Perjalanan $\left(\mathrm{x}_{4}\right)$ dinotasikan dengan persamaan $\mathrm{x}_{4}=\gamma_{45}$ $\mathrm{y}_{5}+\gamma_{46} \mathrm{y}_{6}+\gamma_{47} \mathrm{y}_{7}$ dan persamaan struktural dinyatakan dengan notasi $\mathrm{x}_{4}=\beta_{42} \mathrm{x}_{2}+\varepsilon_{2}$. Berikut ini merupakan nilai estimasi yang terstandarisasi pada gamma $(\gamma)$ dan beta $(\beta)$.

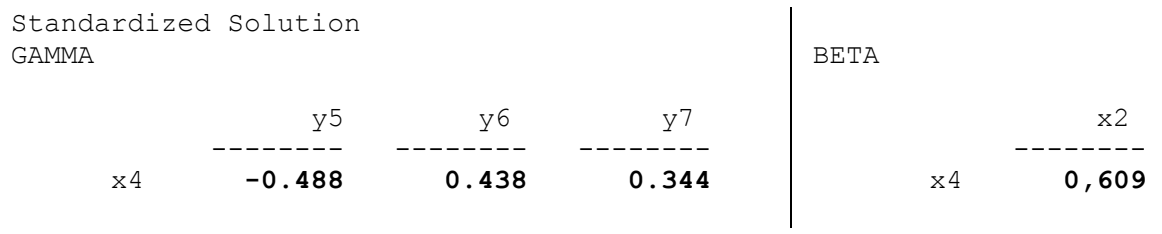

Pengaruh Jarak Tempuh Perjalanan $\left(\mathrm{x}_{2}\right)$ terhadap Biaya Perjalanan $\left(\mathrm{x}_{4}\right)$ lebih kuat dari pengaruh variabel indikator lainnya. Hal ini memang beralasan, sebab jarak tempuh yang semakin panjang akan meningkatkan kebutuhan bahan bakar yang diperlukan bagi pengendara sepeda motor. Biaya Perjalanan dipengaruhi secara langsung oleh Jarak Tempuh Perjalanan dengan tambahan pengaruh secara tidak langsung dari Lokasi Tempat Tinggal $\left(\mathrm{y}_{10}\right)$ dan Trip Frekuensi $\left(\mathrm{x}_{1}\right)$ pekerja. Adanya pengaruh variabel $\mathrm{y}_{10}$ dan $\mathrm{x}_{1}$ terhadap $\mathrm{x}_{4}$, karena Jarak Tempuh Perjalanan $\left(\mathrm{x}_{2}\right)$ bertindak sebagai variabel perantara pada hubungan tersebut.

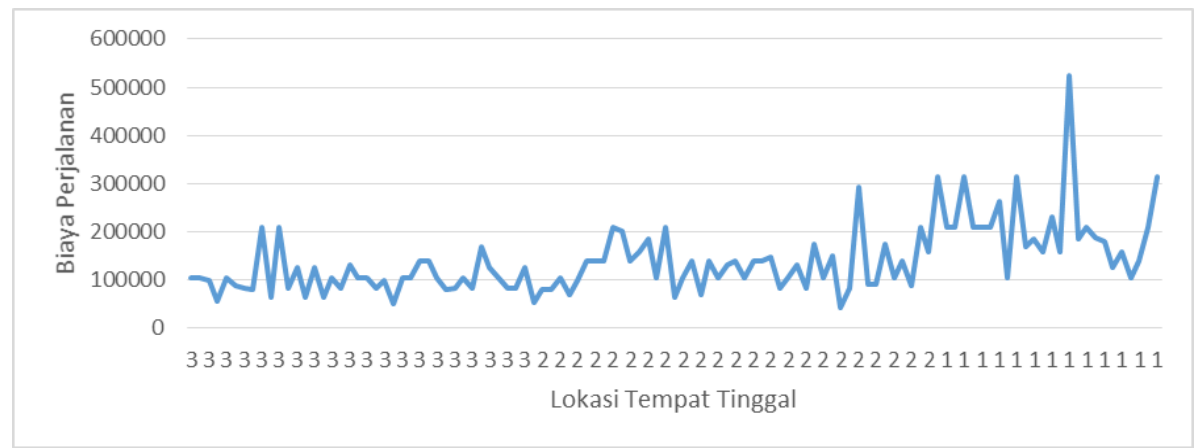

Sumber: Hasil Analisis Peneliti, 2017 


\section{Gambar 7 Biaya Perjalanan Berdasarkan Lokasi Tempat Tinggal}

Lokasi Tempat Tinggal $\left(\mathrm{y}_{10}\right)$ mempengaruhi Biaya Perjalanan secara berbanding lurus atau tetap bermakna positif-positif, meskipun nilai estimasi lokasi tempat tinggal bernilai negatif. Biaya tersebut bertambah karena fungsi jarak yang perlu ditempuh akibat lokasi tempat tinggal yang dekat atau menjauhi tempat kerja. Selain itu, penambahan frekuensi perjalanan mengambarkan partisipasi pekerja terhadap kegiatan lain yang mempengaruhi jarak dan lalu biaya perjalanan. Hal ini terjadi apabila partisipasi pekerja terhadap kegiatan non-bekerja berlokasi di tempat yang tidak sejalur dengan perjalanan pulang-pergi bekerja. Pekerja yang hanya melakukan perjalanan komuter akan melakukan perjalanan simpel dengan frekuensi 2 perjalanan tiap hari. Sedangkan, pekerja dengan frekuensi perjalanan 3 atau lebih akan menempuh jarak tembahan akibat berpartisipasi terhadap kegiatan lain selama perjalanan komuter. Partisipasi tersebut dapat berupa mengantar dan/atau jemput anak/pasangan, melakukan perjalanan belanja atau makan siang/malam. Lokasi tempat tinggal akan lebih kuat mempengaruhi biaya perjalanan, sebab jarak antar rumah dan kantor ialah tetap. Hal itu berbeda dengan peluang partisipasi pekerja terhadap kegiatan non-bekerja yang dapat berbeda tiap harinya saat perjalanan komuter.

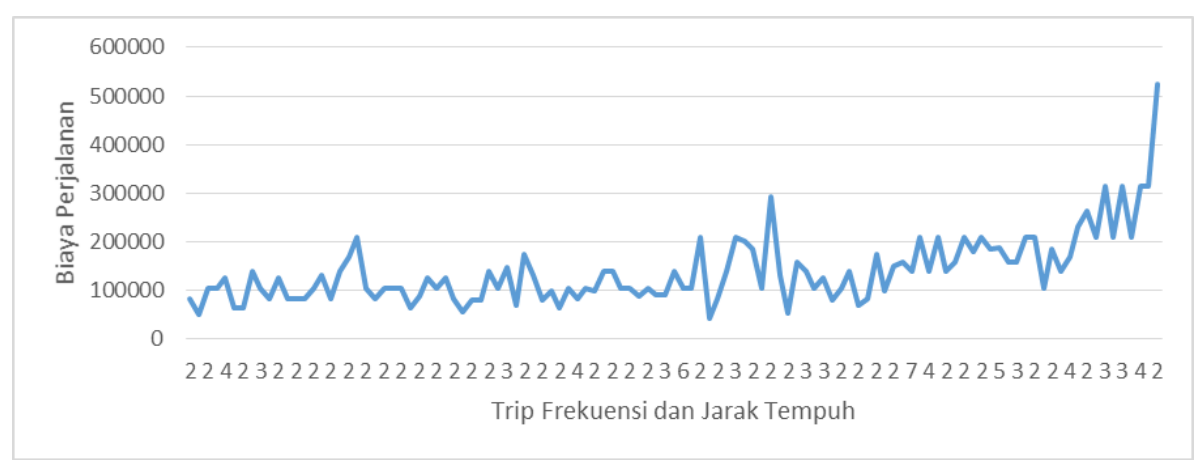

Sumber: Hasil Analisis Peneliti, 2017

\section{Gambar 9 Biaya Perjalanan berdasarkan Trip Frekuensi dan Jarak Tempuh}

Biaya perjalanan juga dipengaruhi secara langsung oleh latar belakang kondisi rumah tangga, meliputi Ukuran Rumah Tangga ( $\left.\mathrm{y}_{5}\right)$, Jumlah Pekerja dalam Rumah Tangga $\left(\mathrm{y}_{6}\right)$ dan Jumlah Anggota Usia Anak dalam Rumah Tangga $\left(\mathrm{y}_{7}\right)$. Nilai negatif pada variabel $\mathrm{y}_{5}$, serta nilai positif pada variabel $\mathrm{y}_{6}$ dan $\mathrm{y}_{7}$ menjelaskan bahwa pekerja yang memiliki anak dan dual-earner, namun memiliki ukuran rumah tangga yang lebih kecil akan memiliki Biaya Perjalanan yang lebih besar. Hal ini dikarenakan tanggungjawab orang dewasa dalam bekerja mengakibatkan peluang sharing moda terjadi lebih besar, karena pekerja perlu melakukan efektifitas waktu dalam bertanggungjawab terhadap anggota keluarga lainnya. 


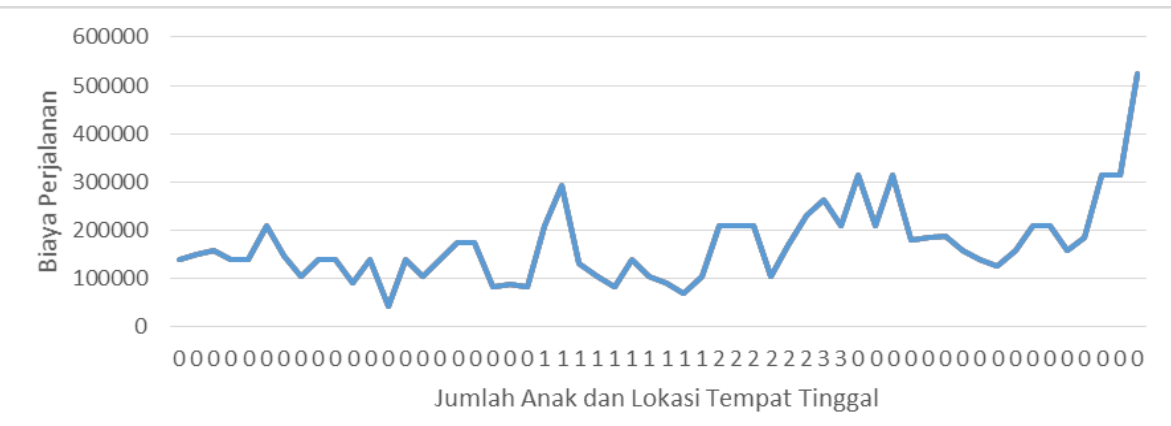

Sumber: Hasil Analisis Peneliti, 2017

\section{Gambar 10 Biaya Perjalanan Berdasarkan Jumlah Anak Dan Lokasi Tempat Tinggal}

Pekerja yang sudah menikah dan telah memiliki anak memiliki tanggungjawab untuk merawat keluarga. Variabel jumlah anak $\left(\mathrm{y}_{7}\right)$ akan mempengaruhi Biaya Perjalanan apabila pekerja berpartisipasi pada kegiatan mengantar/jemput anak atau menitipkan anak, sehingga perlu melakukan perjalanan kompleks saat melakukan perjalanan komuter. Perjalanan yang terdata dalam diari perjalanan, pekerja cenderung hanya melakukan kegiatan mengantar anak ke sekolah karena memiliki waktu berangkat yang sama, yaitu pagi hari. Namun, tidak melakukan kegiatan menjemput karena adanya perbedaan waktu pulang sekolah dan kerja. Apabila pekerja memiliki anak balita, perjalanan perawatan dilakukan dalam bentuk menitipkan anak di pagi hari dan menjemput kembali saat pulang bekerja. Kasus ini ditemui pada perjalanan pekerja yang memiliki anak balita dengan pasangan yang juga bekerja. Untuk pekerja yang belum memiliki anak, biaya perjalanan bertambah sesuai dengan lokasi tempat tinggal dan trip frekuensi yang dilakukan.

\section{Persamaan Pengukuran Durasi Bekerja}

Persamaan pengukuran Durasi Bekerja dinotasikan dengan persamaan $\mathrm{x}_{5}=\gamma_{54} \mathrm{y}_{4}+$ $\gamma_{58}$ y8. Durasi Bekerja merupakan variabel endogen yang dikonstruksi oleh 2 variabel eksogen yaitu Status Pernikahan $\left(\mathrm{y}_{4}\right)$ dan Tingkat Pendapatan Pribadi $\left(\mathrm{y}_{8}\right)$. Hubungan antara variabel eksogen terhadap Biaya Perjalanan dinyatakan dengan nilai gamma $(\gamma)$. Berikut ini merupakan nilai estimasi yang terstandarisasi pada gamma.

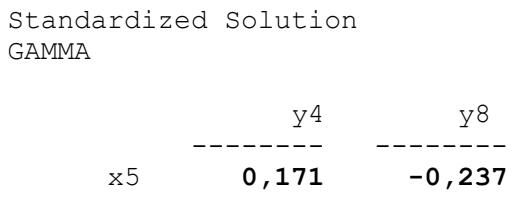

Variabel tingkat pendapatan pekerja ( $\mathrm{y}_{8}$ ) mempengaruhi Durasi Bekerja yang dilakukan pekerja secara negatif dengan nilai -0,237. Pengaruh tersebut membuat pendapatan yang dimiliki akan berbanding terbalik dengan durasi bekerja yang dilakukan. Pekerja dengan tingkat pendapatan yang baik cenderung bekerja secara normal yaitu 8 jam sehari, ketimbang pekerja dengan pendapatan yang lebih rendah. Pekerja dengan gaji dibawah Rp 2.150.000 lebih banyak yang bekerja lebih dari 8 jam. Sedangkan pada rentang gaji Rp 2.150.000-4.250.000 dan > Rp. 4.250.000 lebih banyak pekerja yang bekerja $\leq 8$ jam. 


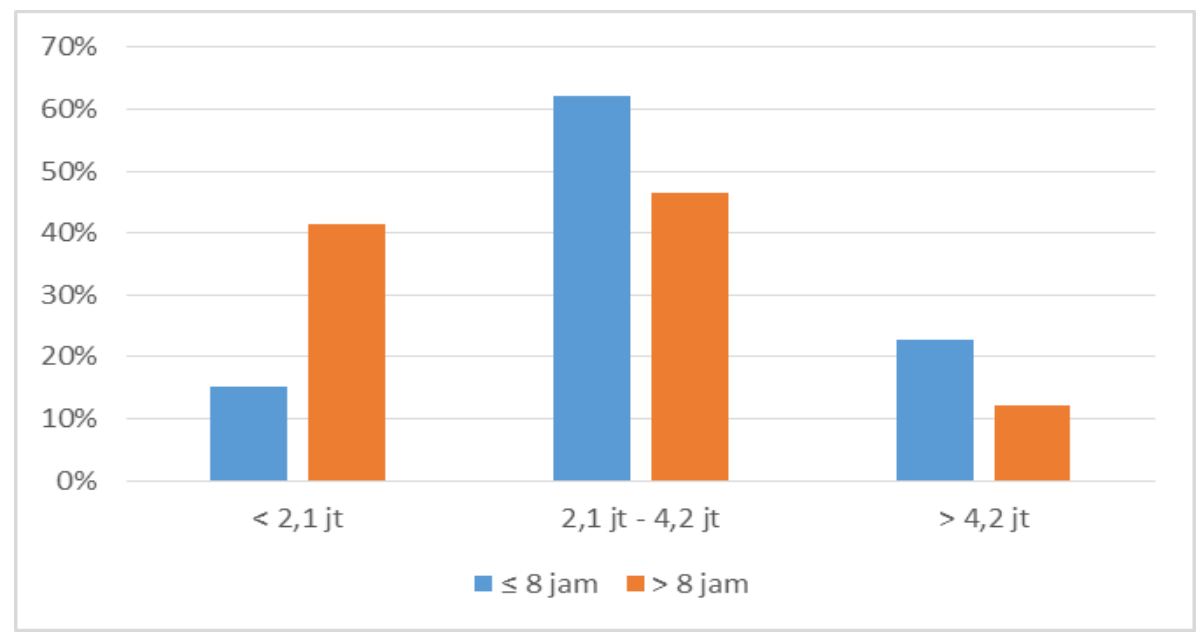

Sumber: Hasil Analisis Peneliti, 2017

\section{Gambar 11 Persentase Durasi Bekerja Berdasarkan Tingkat Pendapatan Pribadi}

Status pernikahan seorang pekerja juga dapat mempengaruhi durasi bekerja yang dilakukannya. Pekerja yang sudah menikah cenderung memiliki durasi bekerja lebih lama dari pekerja yang belum menikah. Hal ini bisa terjadi pada keluarga dengan pencari nafkah tunggul atau memiliki anak namun memiliki pendapatan yang rendah. Pekerja yang sudah menikah memiliki tanggungjawab ekonomi untuk menghidupi keluarganya. Apabila pekerja tersebut memiliki pendapatan yang rendah, maka ia akan melakukan usaha lebih untuk mendapat tambahan pemasukan.

Tabel 6. Pendapatan Pribadi Dan Keberadaan Anak Pada Pekerja Yang Sudah Menikah

\begin{tabular}{|c|c|c|r|}
\hline \multicolumn{2}{|c|}{ Pendapatan Pribadi } & \multicolumn{2}{c|}{ Keberadaan Anak } \\
\hline \multirow{2}{*}{$<2,1 \mathrm{jt}$} & \multirow{2}{*}{$24 \%$} & Tidak Ada & $\mathbf{0} \%$ \\
\cline { 3 - 4 } & & Ada & $100 \%$ \\
\hline \multirow{2}{*}{$2,1 \mathrm{jt}-4,2 \mathrm{jt}$} & \multirow{2}{*}{$50 \%$} & Tidak Ada & $18 \%$ \\
\cline { 3 - 4 } & & Ada & $82 \%$ \\
\hline \multirow{2}{*}{$>4,2 \mathrm{jt}$} & \multirow{2}{*}{$26 \%$} & Tidak Ada & $24 \%$ \\
\cline { 3 - 4 } & & Ada & $76 \%$ \\
\hline
\end{tabular}

Tingkat pendapatan pribadi memiliki korelasi terhadap tingkat pendidikan pekerja, meskipun tidak ada pengaruh tingkat pendidikan pada model fit. Pekerja yang memiliki pendidikan rendah, cenderung memiliki pendapatan yang relatif rendah. Tingkat pendidikan diklasifikasikan menjadi SD (1), SMP (2), SMA/SMK (3), D3 (4), D4/S1 (5), S2 (6), dan S3 (7) pada garis $\mathrm{x}$ (horizontal). Sedangkan Tingkat pendapatan diklasifikasi menjadi < Rp 2,1 jt (1-2), Rp 2,1 jt - 4,2 jt (3-4), dan > Rp 4,2 jt (5-7) pada garis y (vertikal). 


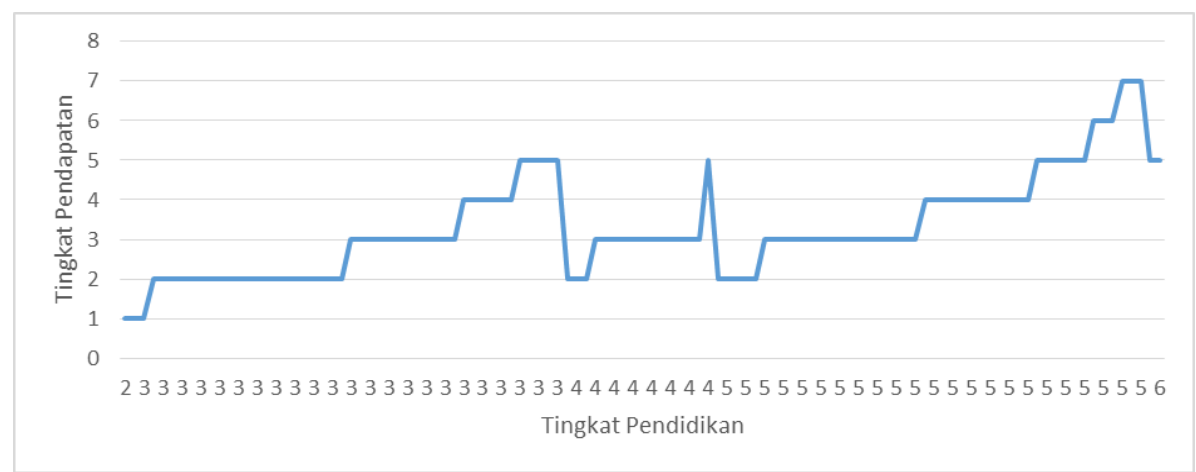

Sumber: Hasil Analisis Peneliti, 2017

\section{Gambar 12 Tingkat Pendapatan Pribadi Berdasarkan Tingkat Pendidikan}

Variabel Durasi Bekerja sebagai variabel perantara menghubungkan pengaruh pendapatan terhadap trip frekuensi. Pekerja dengan 2 kali perjalanan untuk perjalanan komuter, namun memiliki durasi bekerja kurang dari 8 jam disebabkan karena pekerja tersebut melakukan kegiatan non-bekerja selama bekerja di kantor. Pekerja yang memiliki frekuensi perjalanan sebesar 2-3 dan memiliki durasi bekerja lebih dari 8 jam, menjelaskan pekerja tersebut sedang melakukan kerja lembur. Pekerja yang memiliki frekuensi perjalanan lebih dari 4 dan memiliki durasi bekerja yang melebihi 8 jam menjelaskan pekerja tersebut memiliki 2 tempat bekerja. Hal ini terlihat pada pekerja yang memiliki usaha toko atau memiliki dua shift kerja, dimana pekerja tersebut melakukan perjalanan untuk kembali bekerja ditempat yang berbeda atau di tempat yang sama namun berbeda waktu. Hal ini menjelaskan bahwa pendapatan yang rendah membuat pekerja melakukan kerja lembur atau berpartisipasi pada kegiatan bekerja di tempat lain.

Hubungan durasi bekerja dan frekuensi perjalanan dapat digunakan untuk menganalisis kemungkinan pekerja berpindah menggunakan moda selain sepeda motor untuk tujuan bekerja. Pekerja yang memiliki durasi bekerja lebih dari 8 jam dan/atau melakukan perjalanan lebih dari 2 kali saat perjalanan komuter tertutup kemungkinannya untuk dapat bergeser menggunakan Trans Semarang. Hal tersebut karena jam pulang pekerja akan berhimpitan dengan batas akhir operasional Trans Semarang. Pekerja juga akan kesulitan mendapatkan transportasi penghubung dari halte terdekat ke rumah pada malam hari. Penggunaan transportasi paratransit seperti ojek/ojek online akan menambah biaya perjalanan. Selain itu, pekerja yang memiliki tautan perjalanan kompleks menjelaskan adanya partisipasi pekerja terhadap kegiatan non-bekerja selama perjalanan komuter. Apabila pekerja beralih menggunakan transportasi umum, maka perlu ada kegiatan non-bekerja yang dikorbankan. Pada dasarnya, pekerja akan mengambil keputusan dengan mempertimbangkan utilitas, sehingga akan memilih moda yang dapat memberikan manfaat lebih banyak untuk tujuan yang sama. 


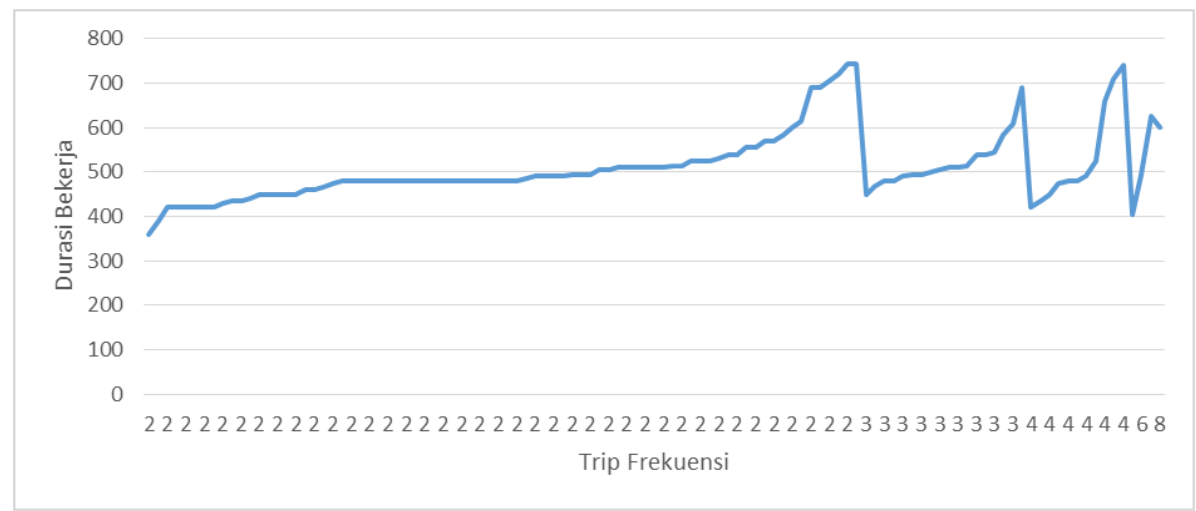

Sumber: Hasil Analisis Peneliti, 2017

\section{Gambar 13 Durasi Bekerja Berdasarkan Trip Frekuensi}

\section{KESIMPULAN}

Preferensi pekerja dalam memilih moda tidak dapat bergeser hanya karena ketersediaan layanan transportasi massal, namun perlu ditunjang dengan jangkauan dan layanan yang baik. Kompleksitas penggunaan Trans Semarang tidak sebanding dengan kemudahan menggunakan sepeda motor untuk memaksimalkan utilitas dalam berkegiatan. Oleh karena itu, perbaikan layanan transportasi massal dan penataan ruang perlu disinkronisasi untuk mengurangi penggunaan kendaraan pribadi.

Berdasarkan hasil penelitian, pekerja yang sudah menikah dengan dual-earner dalam rumah tangga, memiliki 1-2 anak di bawah 17 tahun dan memiliki rumah tangga ukuran kecil merupakan pekerja yang berpeluang untuk melakukan perjalanan kompleks. Selain itu, pekerja dengan jenis kelamin perempuan dan memiliki durasi bekerja $>8$ jam juga lebih berpeluang untuk melakukan perjalanan kompleks daripada perjalanan simpel. Dengan demikian, pekerja yang masih lajang dan belum memiliki anak atau sudah tidak memiliki anak usia sekolah merupakan potensial demand (49,5\%) yang lebih perlu dijangkau untuk dapat beralih moda ke Trans Semarang dan meninggalkan penggunaan sepeda motor.

Pekerja akan mengawali dan mengakhiri perjalanannya di rumah, maka jarak rumah terhadap tempat aktivitas utamanya menjadi suatu hal yang penting untuk diintegrasikan dan perlu dilayani dengan transportasi umum yang baik. Hal ini untuk meningkatkan efektifitas dan efisiensi serta mengurangi kemacetan lalu lintas. Apabila perjalanan komuter tidak terfasilitasi oleh transportasi umum yang baik, maka wajar apabila pekerja mencari solusi alternatif, yaitu dengan menggunakan sepeda motor untuk memenuhi kebutuhan perjalanannya.

\section{UCAPAN TERIMA KASIH}

Ucapan terima kasih kepada Fakultas Teknik Universitas Diponegoro yang telah memberikan bantuan dalam skema Hibah Bersaing Dana DIPA Penelitian Dasar tahun 2017.

\section{DAFTAR PUSTAKA}

Bertolini, L., le Clercq, F., \& Kapoen, L. (2005). Sustainable Accessibility: A conceptual framework to integrate transport and land use plan-making. Two test-applications in the Netherlands and a reflection on the way forward. Transport Policy, 12(3), 207-220. https://doi.org/10.1016/j.tranpol.2005.01.006 
BPS. (2016). Kota Semarang dalam Angka 2016. Katalog 1102001.3374 (Vol. 3). Kota Semarang.

Douglas, G. B., Evans, J. E. J., \& Quade, P. B. (n.d.). Urban Design , Urban Form , And Employee Travel Behavior, 298-306.

Handy, S. (2002). Accessibility- vs. Mobility-Enhancing Strategies For Addressing Automobile Dependence in The U.S. Davis, CA. Retrieved from http://www.des.ucdavis.edu/faculty/handy/ECMT_report.pdf

Hasibuan, H. S., Soemardi, T. P., Koestoer, R., \& Moersidik, S. (2014). The Role of Transit Oriented Development in constructing urban environment sustainability, the case of Jabodetabek, Indonesia. Procedia Environmental Sciences, 20, 622-631. https://doi.org/10.1016/j.proenv.2014.03.075

Ma, J., Mitchell, G., \& Heppenstall, A. (2014). Daily travel behaviour in Beijing, China: An analysis of workers' trip chains, and the role of socio-demographics and urban form. Habitat International, 43, 263-273. https://doi.org/10.1016/j.habitatint.2014.04.008

Maat, K. (2009). Built Environment and Car Travel: Analyses of Interdependencies. Amsterdam: IOS Press BV.

Manoj, M., \& Verma, A. (2013). Trip-Chaining Behaviour of Workers From a City of A Developing Country, 118.

Solimun. (2002). Multivariate Analysis Structural Equation Modelling (SEM) Lisrel dan Amos. FMIPA Universitas Brawijaya.

Susantono, B. (2014). Revolusi Transportasi. Jakarta: Gramedia Pustaka Utama.

Van Acker, V., \& Witlox, F. (2007). Explaining travel behavior: Towards a new conceptual framework and modeling technique. In Proceedings of the 11th World Conference on Transport Research. Retrieved from http://hdl.handle.net/1854/LU-387702

Vilhelmson, B. (1999). Daily mobility and the use of time for different activities. The case of Sweden, $48(3)$, 177-185.

Yang, M., Wang, W., Chen, X., Wan, T., \& Xu, R. (2007). Empirical Analysis of Commute Trip Chaining: Case Study of Shangyu, China. Transportation Research Record, 2038(1), 139-147. https://doi.org/10.3141/2038-18

Ye, X., Pendyala, R. M., \& Gottardi, G. (2007). An exploration of the relationship between mode choice and complexity of trip chaining patterns. Transportation Research Part B: Methodological, 41(1), 96-113. https://doi.org/10.1016/j.trb.2006.03.004 